\title{
DETERMINATION OF ECONOMIC SELECTION INDEX COEFFICIENTS FOR DAIRY COWS ${ }^{1}$
}

\author{
Sanjin Ivanovic ${ }^{2}$, Dragan Stanojevic ${ }^{3}$, Lana Nastic ${ }^{4}$, Marko Jeločnik $^{5}$
}

\begin{abstract}
Summary
There is no research regarding economic effects of genetic improvement for dairy cattle in Serbia. Therefore, the goal of this paper is to determine economic values for various production traits (milk yield, milk fat content and proteins content) in dairy production, as well as to determine total economic selection index. The research is based on data which include 9,516 lactations of 4,893 milking cows from 7 farms. Data were collected during the period $2004-2012$. Authors used sensitivity analysis and partial budgeting approach to determine changes in revenues caused by variations of particular production traits. It was determined that within economic selection index the most important trait is milk yield, while values for other traits are almost negligible. On the other hand, it is expected that importance of certain traits will be changed after Serbian accession to the European Union.
\end{abstract}

Key words: economic selection index, dairy cows, production traits, milk quality, revenue.

JEL: $Q 10, Q 12$

1 Paper is a part of the research on projects: Improvement of biotechnological procedures as a function of rational utilization of energy, agricultural products productivity and quality increase, project no. TR 31051 and Sustainable agriculture and rural development in the function of accomplishment of strategic goals of the Republic of Serbia within the Danube region, project no. III 46006, financed by the Ministry of Education, Science and Technological Development of the Republic of Serbia, for the project period 2011-2014.

2 Ivanović Sanjin, Ph.D., Associate Professor, University of Belgrade, Faculty of Agriculture, Department of Agricultural Economics, Nemanjina Street no. 6, 11080 Zemun, Serbia, Phone: +381 112615 315/ext 426, E-mail: sanjinivanovic@agrif.bg.ac.rs

3 Stanojević Dragan, Assistant, University of Belgrade, Faculty of Agriculture, Department of Zoo Techniques, Nemanjina Street no. 6, 11080 Zemun, Serbia, Phone: +381 112615 315/ext 169, E-mail: stanojevic@agrif.bg.ac.rs

4 Nastić Lana, M.A., Researcher Assistant, Institute of Agricultural Economics, Volgina Street no. 15, 11060 Belgrade, Serbia, Phone: +381 1169728 52, E-mail: lana n@,iep.bg.ac.rs

5 Jeločnik Marko, M.A., Researcher Assistant, Institute of Agricultural Economics, Volgina Street no. 15, 11060 Belgrade, Serbia, Phone: +381 1169728 52, E-mail: marko_j@iep.bg.ac.rs

EP 2014 (61) 4 (861-875) 


\section{Introduction}

Breeding of domestic animals is a complex zoo technical process, as by the goals that have to be achieved, or methods that are applied, as well as by the required organization related to the collection of data necessary for precise assessment of breeding value. This work includes a large number of participants, starting form breeders, basic, regional and central breeding organizations, centres for artificial insemination, professional and scientific organizations and faculties. There are several mutually different goals of domestic animals breeding, where all of them are determined on the basis of long-term plans and programs for development of animal husbandry. Breeding is carried out by selection of parental pairs, after whose mating is obtained generation of descendants, that have to possess more expressed production characteristics of economic importance in compare to the population from which they originated.

Selection of the parental pairs is usually made on the basis of breeding value of the head of cattle. Breeding value represents the value of the genes that will be transferred to the descendants. Assessment of breeding value is a complex process, which includes a large number of impacts. Up today were developed and in use a number of methods for the assessment of the breeding value of domestic animals, such are selection index, BLUP method, BLUP AM method, etc. Advantages of the selection index, as a method for the assessment of breeding value is its relatively simple use, after equation of selection index is determined (Radojković et al., 2010).The selection index was served as a base for the development of contemporary and more reliable methods for the breeding value assessment.

In order to obtain, for production, more economical animals, there is a necessity for carrying out of the selection on number of characteristics. In mentioned selection, having in mind the level of expression of certain characteristics, often are made the compromises. However, in this case, the overall effect of selection is much greater (Vidović, 2008).Within the selection index are combined the production levels of two or more characteristics, obtaining a score based on which is made the selection. Such an obtained score is in maximal correlation with the genetic contribution of certain individual.

At the very beginning of the use of selection indexes in the dairy cattle breeding, accent was on milk and milk fat yield. VanRaden (2002) determined, during his research of selection indexes in use for breeding value assessment of dairy cattle that in six countries (Germany, France, UK, Israel, Australia and New Zealand) in selection indexes are included just milk traits, in three countries (USA, Canada and Italy) around third part of the total value of selection index refers to the characteristics of the dairy cattle type and longevity, while in certain countries, like Denmark, beside mentioned traits are also introduced a reproductive traits, as well as characteristics related to animal health status. Miglior et al. (2005) stated that the most selection indices were based on improving milk yield and outside North America toward increasing fat and protein content. According to authors in recent years there has been growing interest in functional traits such as reproduction and health. According to Berry et al. (2005) ,it is important to bear in mind that some annual traits may be economically relevant in dairy enterprises but not in beef enterprises". Therefore 
authors analyse economic values for number of traits related not only to dairy but also to beef production in Ireland. Approach in which are analysed more traits is important, as unilaterally conducted selection in milk traits lead to the negative effects in udder health (Heringstad et al., 2003) and in animal reproductive performances (Veerkamp et al., 2001; Kadarmideen et al., 2003).

Determination of the economic value of certain traits is the most important and the most complex task during the selection index establishment. According to McArthur (1987), economic value of some trait represents a net amount of cash that is obtained in optimal breeding conditions, when certain trait is improved for one unit.

Main goal of this paper is determination of economic selection index coefficients, which will enable calculation of breeding value of black-white cows in Serbia, as well as their later ranking during the parental pair's selection.

\section{Methodology and data sources}

Initial set of data for calculation of needed parameters, necessary for the establishment of selection index, comprised of 11,235 lactation performed by 5,633 milking cows. They were the descendants of the 83 bulls -sires. From the set of data were excluded all lactation that had incomplete production data. For more precise assessment of the additive genetic component, all bulls with less than 10 daughters were excluded. After that, all lactations which had values for the observed traits above or below three standard deviations were also excluded. After the base data adjustment process, it was defined the final data set, which included 9,516 lactations realized by 4,893 milking cows from 7 farms of PKB corporation within the period 2004 - 2012. Animals were descendants of 59 bulls and all heads were under the A control of a milk yield.

Establishment of the selection index, having in focus milk production, includes traits of primary importance, such are: milk yield (MY), yield of milk fat (fat content - FC) and yield of proteins (protein content - PC).Production results for the observed traits are adjusted to a standard lactation, and like that are used in the process of selection index establishment.

Breeding value, estimated by the use of selection index method, can be presented with the following general equation for the selection index:

$$
\mathrm{I}=\mathrm{b}_{1}\left(\mathrm{X}_{1}-\overline{\mathrm{X}}_{1}\right)+\mathrm{b}_{2}\left(\mathrm{X}_{2}-\overline{\mathrm{X}}_{2}\right)+\ldots \ldots+\mathrm{b}_{\mathrm{n}}\left(\mathrm{X}_{\mathrm{n}}-\overline{\mathrm{X}}_{\mathrm{n}}\right)
$$

Where:

I - relative breeding value evaluated by selection index, or value of selection index determined for certain head of cattle;

$\mathrm{b}_{\mathrm{i}}-$ multiple regression coefficients for each trait included in the selection index;

$\left(\mathrm{X}_{\mathrm{i}}-\overline{\mathrm{X}}_{\mathrm{i}}\right)$ - difference between phenotypic value of trait included in selection index for certain individual and population average for certain trait. 
Starting from the assumption that the correlation between genetic value of individual $(G)$ and selection index value is maximal, it can be come to following equation:

$\mathrm{P} * \mathrm{~b}=\mathrm{G}^{*} \mathrm{v} \quad$ or $\quad \mathrm{b}=\mathrm{G}^{*} \mathrm{v}^{*} \mathrm{P}^{-1}$

Where:

$\mathrm{P}$ - Phenotypic variance-covariance matrix;

b - Multiple regression coefficients for each trait included in the selection index

$\mathrm{G}$ - Genetic variance-covariance matrix;

$\mathrm{v}$ - Vector of relative economic values of the traits included into selection index.

As a matrix, mentioned equation has next form:

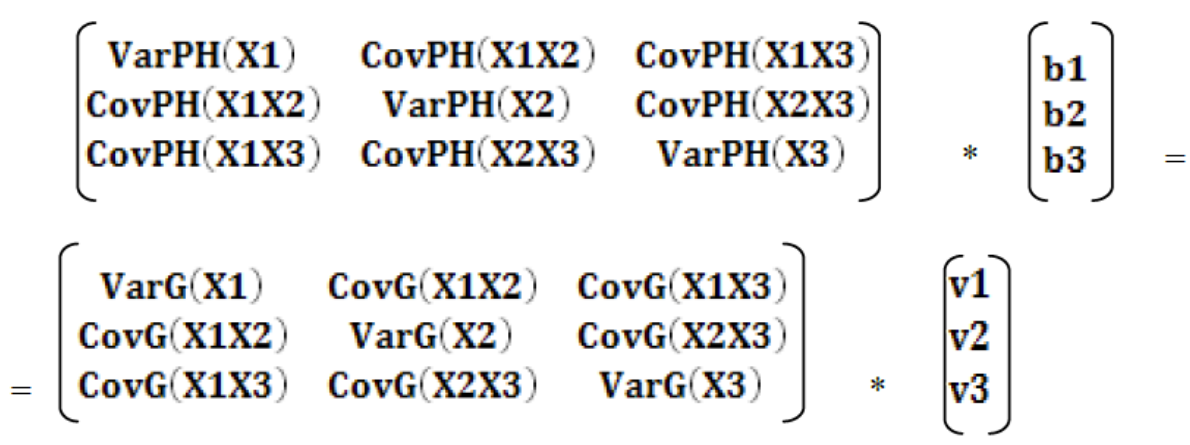

In paper will be presented some of approaches used worldwide in order to calculate the indicator $v$. This is vector of relative economic values of traits included into selection index.

Coefficients of heredity and genetic and phenotypic correlations, in other words values of genetic and phenotypic variances and covariance, were calculated by the method of least squares (Harvey, 1990) and by the application of next mixed model:

$\mathrm{Y}_{\mathrm{ijklm}}=\mu+\mathrm{O}_{\mathrm{i}}+\mathrm{F}_{\mathrm{j}}+\mathrm{L}_{\mathrm{k}}+\mathrm{G}_{1}+\mathrm{S}_{\mathrm{m}}+\mathrm{b}(\mathrm{X}-\overline{\mathbf{X}})+\mathrm{e}_{\mathrm{ijklm}}$

Where:

$\mathrm{Y}_{\mathrm{ijklm}}$ - manifestation of tested trait;

$\mu$ - average of population;

$\mathrm{O}_{\mathrm{i}}$ - random effect of $\mathrm{i}^{\text {th }}$ bull-sire;

$F_{j}$ - fixed effect of $j^{\text {th }}$ farm;

$\mathrm{L}_{\mathrm{k}}$ - fixed effect of $1^{\text {th }}$ lactation;

$\mathrm{S}_{\mathrm{m}}$ - fixed effect of $\mathrm{k}^{\text {th }}$ season of calving;

$\mathrm{b}(\mathrm{X}-\overline{\mathbf{X}})$ - regression effect of part of HF breed genes;

$\mathrm{e}_{\mathrm{ijklm}}$ - random effect of non-determined factors. 
Very detailed review of methods which could be used to derive economic values for various traits in dairy cattle breeding is presented by Groen et al. (1997). There are described objective (modelling - system analysis) versus non-objective methods (desired or restricted gain indices). Authors describe two approaches to modelling. The first is positive approach (data evaluation) which assumes use of historical data. The second is normative (data simulation) approach which uses profit functions and bio-economic models. While describing determination of economic value for dairy cattle Seyedsharifi et al. (2013) stated that risk can be incorporated in this process. Authors describe methods for deriving economic weights, which can be divided into positive (data analysis) and normative (bio-economic modelling) methods. MacNeil et al. (1997) gave an overview of various methodologies that can be used for determination of relative economic values for beef production on farm level. Authors discussed use of profit equations (for male calves, surplus heifer calves and cull cows), sensitivity analysis (on the basis of partial derivative of profit with respect to the parameter), shifts in cost function (marginal costs and marginal revenues are used to determine profit maximizing level of output).

Example of sensitivity analysis use is presented by Miesenberger et al. (1998) for Simmental population in Austria. The analysis started from the herd model dealing with milk production, bull fattening and heifer rearing. There was an assumption of a quota for the sum of fat and protein yields. As entire herd was observed, economic value of a trait is computed on the basis of profit on farm per year before and after a genetic change. Toivakka et al. (2005) also used level of herd and sensitivity analysis to determine economic value of various biological and functional traits in Finnish dairy cattle production. Similar approach for construction of economic selection index is used by Khan and Mazumder (2011) for individual dairy cows of different dairy breed groups on different farms in Bangladesh. There were observed three traits (lactation milk yield, calving interval and live weight). There was used linear profitability model on which was applied sensitivity analysis (the economic value of individual traits was obtained by re-running the base model after changing one unit of each trait while maintaining the other traits at a constant level).

Steine et al. (2008) applied profit function to estimate the economic values of the traits included in the breeding goal for Norwegian Red dairy cattle. Authors observed 10 traits using data from more than 3,000 Norwegian dairy farms over period of five years. The data set consisted of farm-level data as well as estimated breeding values for each cow's sire. Results indicated that selection has led to shift in profits of the farms. Profit function was also used by Komlósi et al. (2010) to estimate economic values of 15 traits for Hungarian Holstein - Friesian cattle. Authors also determined relative economic importance of each trait or trait component. Hietala et al. (2014) used "calculation of revenues and costs for each animal group and the total profit of production based on a function of biological, economic and management parameters" to determine economic value of traits in Finnish dairy production. In this paper authors used discounted revenues and costs, which means that time value of money was taken into account. On the other hand, Roibas and Alvarez (2010) used production function (production frontier approach) rather than profit function. Production function enabled authors to calculate the increase in milk production and farm 
profit associated with a change in genetic level. For the analysis authors used gross margins calculated for various scenarios.

To determine economic selection index for dairy caws, all partial economic weights (selection index coefficients) for all observed traits have to be calculated, which is the goal of this paper. Selection index coefficient is economic value of genetically improved certain trait. At the same time all other traits are unchanged.

\section{Results with discussion}

In Table 1 are presented average values and variability of dairy traits in standard lactation that were achieved by observed heads of cattle. Presented data of milk yields are used as a base for determination of partial economic weights for observed traits.

Table 1. Indicators of phenotypic manifestation and variability of milk yield traits in standard lactation

\begin{tabular}{|c|c|c|c|c|c|}
\hline Traits & $\mathbf{n}$ & $\overline{\mathbf{X}}$ & SD & min & max \\
\hline MY (kg) & \multirow{4}{*}{ \%FC (\%) } & 8,261 & 1,650 & 3,373 & 13,597 \\
\cline { 4 - 6 } & \multirow{4}{*}{9,516} & 3.57 & 0.192 & 2.92 & 4.25 \\
\cline { 4 - 6 } & & 294.14 & 59.16 & 120.43 & 481.58 \\
\cline { 4 - 6 } & & 3.27 & 0.109 & 2.89 & 3.65 \\
\hline Yield of milk fat (kg) & 270.07 & 52.71 & 111.50 & 439.20 \\
\hline
\end{tabular}

Source: Calculation according Authors' research.

Notes: MY- milk yield; \%FC - milk fat content; \%PC - milk proteins content.

Observed herd of animals, in standard lactation, in average, produced 8,261 $\mathrm{kg}$ of milk with $294.14 \mathrm{~kg}$ of milk fat and $270.07 \mathrm{~kg}$ of protein. Determined values are significantly higher than the values recorded in researches on same population by Đedović (2000), Beskorovajni (2000) and Carlen et al. (2004). After comparison of determined values for observed traits with the results recorded by Beskorovajni (2014), milk yield and milk fat in standard lactation have higher values, while the value for the content of milk fat is in line with gained results of mentioned author.

Within the study was examined the impact of fixed factors on phenotypic expression and variability of milk production traits in standard lactation, like are farms, lactations, years and seasons in which the observed heads of cattle were in production. In Table 2 are given the values of F-test for the examined factors. 
Table 2. F-test values for the researched factors

\begin{tabular}{|l|c|c|c|c|c|}
\hline \multirow{2}{*}{\multicolumn{1}{c|}{ Trait }} & \multicolumn{5}{|c|}{ F value } \\
\cline { 2 - 5 } & Farm & Lactation & Year & $\begin{array}{c}\text { Calving } \\
\text { season }\end{array}$ & $\begin{array}{c}\text { Model } \\
\text { determination }\left(\mathbf{r}^{2}\right)\end{array}$ \\
\hline Milk yield (kg) & $14.96^{* *}$ & $211.10^{* *}$ & $15.74^{* *}$ & $50.14^{* *}$ & 0.223 \\
\hline Content of milk fat (\%) & $66.85^{* *}$ & $6.66^{* *}$ & $24.65^{* *}$ & $6.33^{* *}$ & 0.056 \\
\hline Yield of milk fat (kg) & $32.68^{* *}$ & $187.34^{* *}$ & $21.98^{* *}$ & $43.11^{* *}$ & 0.208 \\
\hline Content of proteins (\%) & $72.84^{* *}$ & $6.19^{* *}$ & $30.42^{* *}$ & $25.75^{* *}$ & 0.048 \\
\hline Yield of proteins (kg) & $18.34^{* *}$ & $211.63^{* *}$ & $17.36^{* *}$ & $40.93^{* *}$ & 0.224 \\
\hline
\end{tabular}

Source: Calculation according Authors' research.

Notes: ${ }^{* *}$ statistically there is a highly significant difference $(\mathrm{p}<0.01)$.

Analysed factors had statistically highly significant $(\mathrm{p}<0.01)$ impact on all observed traits in the standard lactation. To similar results, in their researches, had also came Latinović et al. (1990), Stanojević et al. (2012) and Beskorovajni (2014).

Having in mind the heritability of observed milk traits in standard lactation, in available literature sources can be encountered values that have a wide interval of variation. Coefficients were calculated by method of interclass correlation per sire by use of mixed model. Determined values for the heredity coefficients, as well as their errors are presented in Table 3.

Table 3. Values of the coefficient $\left(h^{2}\right)$ - heredity of milk traits in standard lactation and their errors $\left(S_{h}^{2}\right)$

\begin{tabular}{|l|c|c|}
\hline \multicolumn{1}{|c|}{ Trait } & $\mathbf{h}^{\mathbf{2}}$ & $\mathbf{S}_{\mathbf{h}}{ }^{2}$ \\
\hline Milk yield (kg) & 0.199 & 0.037 \\
\hline Content of milk fat (\%) & 0.078 & 0.018 \\
\hline Yield of milk fat (kg) & 0.185 & 0.035 \\
\hline Content of proteins (\%) & 0.042 & 0.012 \\
\hline Yield of proteins (kg) & 0.20 & 0.037 \\
\hline
\end{tabular}

Source: Calculation according Authors' research.

Values of the heredity coefficients ranged from 0.042 (having in focus the content of protein in milk), to 0.20 for the protein yield. Determined values of the heredity coefficients are significantly lower compared to those recorded by Trifunović (1992), Carlen et al. (2004) and Hung et al. (2008), but much higher compared to the results recorded by Stanojević et al. (2012) and Đedović et al. (2013).To similar values came Stanojevic et al. (2013) and Beskorovajni (2014).Obtained values for the heredity coefficients of dairy traits indicate the possibility of their improvement through selection, although the dominant impact on their expression has the environment factors.

For calculation of economic selection index in paper will be used three indicators- quantity of produced milk, content ( $\%$ ) of milk fat and content ( $\%$ ) of proteins. Use of mentioned elements for the development of the economic selection index is primarily caused by data availability. Despite all limitations, on that way determined economic selection index possesses required key elements that are in use worldwide. In this paper the economic value of a trait will 
represent the change in revenue from milk, as a result of its unit change. Therefore, the goal of this selection approach will be revenue maximization. On the other hand, profit maximization is not a goal of this paper because of following reasons:

- To calculate profit it is needed to deduct production costs from revenues. Therefore, milk production costs should be determined and separated from total costs of cattle production, which is rather complicated procedure;

- Milk production costs differ for various dairy farms. Costs depend on production technology and equipment, not only in milk production, but also in fodder production;

- Therefore, economic selection index based on changes in revenues has wider application and it can be used on farms of various size, which possess different facilities, equipment and production technology, etc.;

- Such approach enables use of economic selection index at different levels (from animal level, individual farm level, to larger number of farms or entire population).

In paper will be shown, what kind of economic effects will be reached by partial economic weight (economic value of the trait), if milk production per cow increases for $1 \mathrm{~kg}$ of milk, as well as if content of milk fat increases for $1 \%$, or if content of proteins grows for $1 \%$. For the economic effects of the milk production growth will be used the price for one litter of milk. However, here occurs the problem that the milk price depends on the content of milk fat and proteins, or in other words, all three indicators are mutually correlated. So, it is necessary to separate the economic effects of increase of mentioned indicators.

This problem was solved in following way - for milk price was taken the price obtained for the milk with basic content of milk fat and protein (i.e. price obtained for the milk before manifestation of the selection effects). On the other hand, partial economic weight for milk fat and proteins is the increase in milk price caused by the growth of the milk fat percentage (i.e. growth of proteins percentage) for one unit. It should be kept in mind that during the calculations, from the market price of milk are excluded subsidies provided by the government, as they do not depend on the content of fat and proteins in milk.

In milk price calculation it was started from the price, paid by the largest dairy plant in Serbia, which purchases around $50 \%$ of total quantity of the raw milk delivered from farms in Serbia. Method for determination of the maximal price for the milk of extra class is shown in Table 4. It can be noticed that in entire maximal milk price, increase of protein and milk fat content (compared to standards) has very low contribution in the growth of milk price.

Table 4. Factors that affect the price of extra class milk

\begin{tabular}{|l|r|}
\hline \multicolumn{1}{|c|}{ Factors } & Value (RSD/I) \\
\hline Initial price for the extra class milk & $\mathbf{2 8 . 5 0}$ \\
\hline Incentives for the extra class & 5.50 \\
\hline Bonus for the extra class & 0.80 \\
\hline Bonus for the registered farms & 1.00 \\
\hline
\end{tabular}




\begin{tabular}{|l|r|}
\hline \multicolumn{1}{|c|}{ Factors } & Value (RSD/l) \\
\hline Bonus for the delivered quantity & 3.50 \\
\hline Price of standard quality milk (according to dairy plant standards) & $\mathbf{3 9 . 3 0}$ \\
\hline Price growth because of increase of percent of proteins regarding to dairy plant standard & 0.30 \\
\hline Price growth because of increase of percent of milk fat regarding to dairy plant standard & 0.40 \\
\hline Maximal price for the extra class milk & $\mathbf{4 0 . 0 0}$ \\
\hline
\end{tabular}

Source: Standards used by the dairy plant and authors' calculation

In further analysis all incentives and disincentives that can be obtained according to quality class of milk were excluded from the calculation of the milk price. Also, bonuses that dairy plants pay to the registered farms, price corrections related to the content of dry matter in milk, or inadequate temperature of milk, etc., will not be taken into account. From the price of milk should be also excluded bonuses that some dairy plants are giving to producers according to the total quantity of the raw milk delivered from the farm.

All mentioned corrections in milk price calculation allow the application of this methodology without any additional corrections (since the calculation is based on common baselines), as on cattle from large farms, as well as on animals from small family farms. Requirement is that on farms is produced extra or first class milk. It is especially important for family farms which increasingly invest in order to enlarge number of cows. It has been proved that such investments are economically efficient (Gogić et al., 2012).

On the other hand, imperfection of this method is that it will minimize, in some extent, the significance of partial economic weight of cow's milk yield and increase the significance of partial economic weights for the growth of milk fat and proteins in milk, what peculiarly refers to the large farms.

Generally, presented procedure is in line with the sensitive analysis approach that is suggested by number of authors focused on aforementioned problem. So, it is monitored for how much income in milk production will be changed by changing one parameter, while other parameters stay fixed. If all three observed indicators are considered together (growth of produced milk quantity, growth of milk fat and proteins content), total economic selection index will express annual growth of revenues from produced milk (per head of cattle, on one farm, on group of farms, in certain wider population), caused by the improvement of observed genetic traits.

Described approach is partly based on partial budgeting method, which is described in detail by many authors, such as Gogić (2014), Kay et al. (2004) and Andrić (1998). By this approach are not considered all incomes and costs of certain production, but only their change caused by the change that occurs in production (in this case improvement of genetic traits of cows). Method tracks just the changes in incomes of final products, in this case that are the incomes from the milk sale. Partial budgeting method does not follow the change of fixed production costs and overhead costs, as they have no impact on the change in profit. Reason for that can be find in fact that there is no additional investment in facilities, equipment, or land. So effects of selection are occurred in unchanged production conditions. In line to previously mentioned, unlike the usual use of the partial budgeting method, here will be not tracked the 
changes in costs caused by selection (e.g. changes in food costs that grow due to growth of milk yield per one cow).

Based on previous considerations, calculation of partial economic weights was performed, after determination of milk price gained for the milk of observed cow's population. This was done by correction of basic milk price given by dairy plant, based on variation in milk fat and proteins content in compare to observed cows. Content of milk fat and proteins differs from dairy plant standards (Table 5).

Table 5. Content of milk fat and content of proteins in milk

\begin{tabular}{|l|c|c|c|}
\hline \multicolumn{1}{|c|}{ Indicator } & $\begin{array}{c}\text { Dairy plant } \\
\text { standard }\end{array}$ & $\begin{array}{c}\text { Average for the cattle } \\
\text { covered with research }\end{array}$ & $\begin{array}{c}\text { Deviation from dairy } \\
\text { plant standard }\end{array}$ \\
\hline Content of milk fat (\%) & 3.80 & 3.57 & -0.23 \\
\hline Content of proteins (\%) & 3.20 & 3.27 & +0.07 \\
\hline
\end{tabular}

Source: Calculation according Authors' research

Initial price of milk of extra and first class quality reduced for mentioned incentives amounts at 28.50 RSD/1, but after its correction for the deviations from dairy plant standards (regarding content of milk fat and proteins), it will be obtained the milk price for all observed cattle in amount of $28.38 \mathrm{RSD} / 1$.

After focusing on method used by dairy plant for the payment of increased percent of milk fat and proteins, following partial economic weights (selection index coefficients) are determined (Table 6).

Table 6. Partial selection index coefficients

\begin{tabular}{|l|c|}
\hline \multicolumn{1}{|c|}{ Indicator } & Partial economic weights \\
\hline Growth of milk yield (RSD/1) & 28.38 \\
\hline Growth of milk fat content for 1\% (RSD/l) & 1.00 \\
\hline Growth of milk proteins content for 1\% (RSD/1) & 1.50 \\
\hline
\end{tabular}

Source: Calculation according Authors' research

Bearing in mind that selection is expected to provide increase in milk yield, as well as in milk fat and proteins content, total economic selection index will be calculated by following formula:

$\mathrm{ESI}=(\mathrm{MYI}$ x 28.38) $+($ MYI x GFC x 1.00) $+($ MYI x GPC x 1.50)

Where:

MYI - milk yield increase,

GFC - growth of milk fat content,

$\mathrm{GPC}-$ growth of proteins content.

For example, breeding goal for the Holstein - Friesian cattle in Serbia is achieving of average milk production in standard lactation of minimum $9,000 \mathrm{~kg}$ of milk with $4.00 \%$ of milk fat and 3.50\% of proteins (Institute for animal husbandry, 2010). 
After the change of planned production volume from kilograms to litters, it will be gained the ESI value of 20,929.70. On that way, it can be also determined ESI for individual head of cattle or single farms, and these ESI can be mutually compared in order to make appropriate conclusions about the selection effects.

\section{Conclusion}

In paper are presented different ways for determination of economic selection index (partial selection index coefficients, as their elements) which are in use worldwide. Also, it was explained the way for mentioned indicators calculation that is possible according to data available in Serbia. Obtained results point out the fact that dairy plants in Serbia usually pay for milk quantity, while its quality does not play significant role within the process of repurchase price determination. Even a large increase in milk fat and proteins content will lead to just negligible increase of milk price. Such an orientation of dairy plants leads to disvalue of activities undertaken by selection service in milk quality improvement.

It can be expected that the dairy plants will change used method in repurchase milk price determination after Serbia access the EU and get some limitations in terms of allowable volume of produced milk. In that case much more attention will be paid to the milk quality (content of milk fat and proteins) than the produced quantity. At that moment previous work of breeders, on improvement of mentioned parameters, will be considered as economically justified.

\section{Literature}

1. Andrić, J. (1998): Troškovi i kalkulacije u poljoprivrednoj proizvodnji, class book, Savremena administracija, Belgrade.

2. Berry, D. P., Shalloo, L., Cromie, A. R., Olori, V. E., Amer, P. (2005): Economic Breeding Index for Dairy Cattle in Ireland, Dairy Production Department, Teagasc, Moorepark Production Research Center, Fermoy, Co. Cork, Ireland.

3. Beskorovajni, R. (2000): Mogućnost unapređenja proizvodnje mleka korišćenjem visoko kvalitetnih bikova, Master thesis, Faculty of Agriculture, Belgrade.

4. Beskorovajni, R. (2014): Genetski trend osobina mlečnosti praćenih u progenom testu bikova crno-bele $i$ holštajn frizijske rase, Doctoral thesis, Faculty of Agriculture, Belgrade.

5. Carlen, E., Strandberg, E., Roth, A. (2004): Genetic Parameters for Clinical Mastitis, Somatic Cell Score and Production in the First Three Lactations of Swedish Holstein Cows, Journal of Dairy Science, vol. 87, pp. 3062-3070.

6. Đedović, R. (2000): Uticaj nivoa mlečnosti na genetsku varijabilnost i povezanost osobina mlečnosti u populaciji crno-belih krava, Master thesis, Faculty of Agriculture, Belgrade. 
7. Đedović, R., Bogdanović, V., Stanojević, D., Beskorovajni, R., Trivunović, S., Petrović, M., Samolovac, Lj. (2013): The assessment of the selection effects on milk yield traits in black-white cattle, $23^{\text {rd }}$ International symposium - New Technologies in Contemporary Animal Production, Novi Sad, Serbia, pp. 18-21.

8. Gogić, P. (2014): Teorija troškova sa kalkulacijama - u proizvodnji $i$ preradi poljoprivrednih proizvoda, class book, III edition, Faculty of Agriculture, Belgrade.

9. Gogić, P., Ivanović, S., Nastić, L. (2012): Investments in dairy farms enlargement in Serbia: A tool for poverty reduction in rural areas. African Journal of Business Management, vol. 6, no. 1, pp. 422-429.

10. Groen, A. F., Steine, T., Colleau, J. J., Pedersen, J., Pribyl, J., Reinsch, N. (1997): Economic values in dairy cattle breeding, with special reference to functional traits. Report of an EAAP - working group, Journal Livestock Production Science, vol. 49, no. 1 , pp. $1-21$.

11. Hung, P. M., Quyen, P. V., Tinh, N. H., Vien, N. T., Duc, N. V., Tuan T. V. (2008): Genetic parameters of dairy cattle at some dairy farms (In Vietnamese), Animal Husbandry Scientific and Technical Magazine of Vietnam, vol. 107, pp 4-6.

12. Harvey, W. R. (1990): User's guide for LSMLMW and MIXMDL, PC-2 Version.

13.Heringstad, B., Chang, Y. M., Gianola, D., Klemetsdal, G. (2003): Genetic analysis of longitudinal trajectory of clinical mastitis in first-lactation Norwegian Cattle, Journal of Dairy Science, vol. 86, pp. 2676-2683.

14. Hietala, P., Wolfová, M., Wolf, J., Kantanen, J., Juga, J. (2014): Economic values of production and functional traits, including residual feed intake, in Finnish milk production, Journal of Dairy Science, vol. 97, no. 2, pp. 1092-1106.

15. Kadarmideen, H. N., Thompson, R., Coffey, M. P., Kossaibati, M. A. (2003): Genetic parameters and evaluations from single-and multiple-trait analysis of dairy cow fertility and milk production, Journal Livestock Production Sciences, vol. 81, pp. 183-195.

16. Kay, R. D., Edwards, W. M., Duffy, P. A. (2004): Farm management, V edition, McGrawHill, New York, USA.

17. Khan, K., Mazumder, J. (2011): Economic selection index using different milk production traits of Holstein and its crossbreds, Turkish Journal of Veterinary and Animal Sciences, vol. 35 , no. 4, pp. 255-261.

18. Komlósi, I., Wolfová, M., Wolf, J., Farkas, B., Szendrei, Z., Béri, B (2010): Economic weights of production and functional traits for Holstein-Friesian cattle in Hungary, Journal of Animal Breeding and Genetics, vol. 127, no. 2, pp. 143-153.

19. Latinović, D., Lazarević, Lj., Katić, M., Stojić, P. (1990): Ocena priplodne vrednosti bikova primenom LS i BLUP metoda, Zbornik radova Biotehniške fakultete Univerze Edvarda Kardelja, Ljubljana, vol. 15, p. 365. 
20. MacNeil, M. D., Nugent, R. A., Snelling, W. M. (1997): Breeding for Profit: an Introduction to Selection Index Concepts, Proceedings, Range Beef Cow Symposium, paper 142, pp. 1-17.

21. McArthur, A. T. G. (1987): Weighting breeding objectives - an economic approach, Proceedings, VI Annual Conference of Australian Association of Animal Breeding and Genetics, Perth, Western Australia, pp. 170-187.

22. Miesenberger, J., Sölkner, J., Essl, A. (1998): Economic weights for fertility and reproduction traits relative to other traits and effects of including functional traits into a total merit index, Proceedings, International Workshop on Genetic Improvement of Functional Traits in Cattle, Grub, Germany, Interbull - Bulletion, vol. 18, pp. 78-84.

23. Miglior, F., Muir, B. L., Van Doormaal, B. J. (2005): Selection indices in Holstein cattle of various countries, Journal of Dairy Science, vol. 88, pp. 255-1263.

24. Radojković, D., Petrović, M., Mijatović, M., Radović, Č. (2010): Metodologija za procenu priplodne vrednosti svinja na osnovu osobina plodnosti primenom selekcijskih indeksa, Biotechnology in Animal Husbandry, vol. 26 - spec. issue, pp. 113-121.

25. Roibas, D., Alvarez, A. (2010): Impact of genetic progress on the profits of dairy farmers, Journal of Dairy Science, vol. 93, pp. 4366-4373.

26. Seyedsharifi, R., Shadparvar, A. A., Hosseinzadeh, N. G. (2013): Development of breeding objectives for dairy cattle: Determination of economic value, Journal of Food, Agriculture \& Environment, vol. 11, no. 1, pp. 346-348.

27. Stanojević, D., Đedović, R., Bogdanović, V., Beskorovajni, R., Perišić, P., Popovac, M., Popović, N. (2013): Heritability and repeatability estimation of milk yield traits of black and white cows, Proceedings of the $10^{\text {th }}$ International Symposium - Modern Trends in Livestock Production, Institute for Animal Husbandry, Belgrade, Serbia, pp. 441-448.

28. Stanojević, D., Đedović, R., Bogdanović, V., Popovac, M., Perišić, P., Beskorovajni, R. (2012): Fenotipska i genotipska varijabilnost i povezanost osobina mlečnosti prvotelki crno-bele rase, Zbornik radova sa XXVI savetovanja agronoma, veterinara, tehnologa $\mathrm{i}$ agroekonomista, pp. 15-22, Belgrade.

29. Steine, G., Kristofersson, D., Guttormsen, A. G. (2008): Economic Evaluation of the Breeding Goal for Norwegian Red Dairy Cattle, Journal of Dairy Science, vol. 91, pp. 418-426.

30. Trifunović, G. (1992): Ispitivanjefenotipske i genetske varijabilnosti i povezanosti osobina telesne razvijenosti, mlečnosti i plodnosti crno-belih goveda, Doktorska disertacija, Poljoprivredni fakultet, Univerzitet u Beogradu, Beograd.

31. Toivakka, M., Nousiainen, J. I., Mäntysaari. E. A. (2005): Estimation of economic values of longevity and other functional traits in Finnish dairy cattle, Paper CG2.25, $65^{\text {th }}$ Annual Meeting of the EAAP, Uppsala, Sweden, available at: www.eaap.org/Previous_Annual Meetings/2005Uppsala/Papers/CG2.25_Toivakka.pdf 
32. Van Raden, P. M. (2002): Selection of dairy cattle for lifetime profit, Proceedings, $7^{\text {th }}$ World Congress on Genetics Applied to Livestock Production, Montpellier, France, pp. 127-130.

33. Veerkamp, R. F., Koenen, E. P. C., De Jong, G. (2001): Genetic correlations among body condition score, yield and fertility in first-parity cows estimated by random regression models, Journal of Dairy Science, vol. 84, pp. 2327-2335.

34. Vidović, V. (2008): Principi i metodi oplemenjivanja životinja, class book, University in Novi Sad, Faculty of Agriculture.

35. Institute for animal husbandry (2010): Glavni odgajivački program u govedarstvuHoštajn frizijska rasa, Belgrade, available at: www.scribd.com/doc/122492515/GlavniOdgajivacki-Program-GOVEDARSTVO-HF, accessed at 01.10.2014. 


\title{
UTVRĐIVANJE KOEFICIJENATA EKONOMSKOG SELEKCIJSKOG INDEKSA ZA MLEČNE KRAVE
}

\author{
Sanjin Ivanović, Dragan Stanojević ${ }^{7}$, Lana Nastic ${ }^{8}$, Marko Jeločnik ${ }^{9}$ \\ Sažetak
}

U Republici Srbiji do sada ne postoje istraživanja koja se odnose na ekonomske efekte genetskog unapređenja mlečnih krava. Zbog toga je cilj ovog rada utvrđivanje ekonomske vrednosti za različite proizvodne osobine (prinos mleka u standardnoj laktaciji, sadržaj mlečne masti i sadržaj proteina) u proizvodnji mleka, kao i da utvrdi ukupni ekonomski selekcijski indeks. Istraživanje je bazirano na podacima koji obuhvataju 9.516 laktacija 4.893 muznih krava sa 7 farmi. Podaci su prikupljeni tokom perioda 2004-2012. godina. Autori su koristili senzitivnu analizu, kao i metod diferencijalne kalkulacije da bi utvrdili promene u prihodima uzrokovane variranjem pojedinačnih proizvodnih osobina. Utvrđeno je da je u okviru ekonomskog selekcijskog indeksa najvažnija osobina prinos mleka u standardnoj laktaciji, dok su vrednosti ostalih proizvodnih osobina gotovo zanemarljive. Sa druge strane, očekuje se da će se značaj pojedinih proizvodnih osobina promeniti nakon pristupanja Srbije Evropskoj Uniji.

Ključne reči: ekonomski selekcijski indeks, mlečne krave, proizvodne osobine, kvalitet mleka, prihod.

6 Prof. dr Ivanović Sanjin, vanredni profesor, Univerzitet u Beogradu, Poljoprivredni fakultet, Institut za agroekonomiju, Nemanjina 6, 11080 Zemun, Srbija, Telefon: +381 112615 315/ lok 426, E-mail: sanjinivanovic@agrif.bg.ac.rs

7 Stanojević Dragan, asistent, Univerzitet u Beogradu, Poljoprivredni fakultet, Institut za zootehniku, Nemanjina 6, 11080 Zemun, Srbija, Telefon: +381 112615 315/lok 169, E-mail: stanojevic@agrif.bg.ac.rs

8 Nastić Lana, M.A., istraživač saradnik, IEP, Volgina 15, 11060 Beograd, Srbija, Telefon: +381 1169728 52, E-mail: lana_n@,iep.bg.ac.rs

9 Jeločnik Marko, M.A., istraživač saradnik, IEP, Volgina 15, 11060 Beograd, Srbija, Telefon: +381 1169728 52, E-mail: marko_j@iep.bg.ac.rs

EP 2014 (61) 4 (861-875) 